\title{
Conter o incontível: apontamentos sobre os conceitos de 'estrutura' e 'espontaneidade' em Grotowski
}

\author{
Tatiana Motta Lima
}

Uma lata existe para conter algo, mas quando o poeta diz "Lata" pode estar querendo dizer o incontivel. [...] Na lata do poeta tudo-nada cabe, pois ao poeta cabe fazer com que na lata venha a caber o incabivel (Gilberto Gil).

\section{Introdução}

s palavras 'partitura', 'estrutura', 'vida' e 'espontaneidade' estão presentes em grande parte dos textos e práticas que se debruçam sobre o trabalho do ator. Também as palavras 'impulso', 'ação física', 'organicidade', 'precisão'. Essas palavras tornaram-se indispensáveis no léxico de um certo tipo de teatro preocupado com o ator; entretanto elas têm sido usadas freqüentemente como se fossem auto-explicáveis e, por esse motivo, têm servido de referência a inúmeros procedimentos artísticos, mesmo antagônicos. Além disso, como se configuram como 'palavras de ordem', não pa- rece muito elegante perguntar o seu significado, uma vez que todos deveríamos saber do que estamos falando.

Temos o direito de usar as palavras como assim nos aprouver e sabemos que, algumas vezes, leituras a princípio equivocadas podem levar a experiências artísticas bastante interessantes. Por outro lado, lançar certas questóes sobre palavras que parecem já compreendidas ou discordar de certas 'leituras' pode ser um exercício que, além de interessante, colabore para levar inquietação e novos estímulos para as nossas salas de trabalho e nossos próximos textos. É a esse exercício que pretendo me dedicar neste artigo.

Muitas das palavras enumeradas acima são encontradas nos textos de Grotowski e citadas, quase sempre, tendo explícita ou implicitamente o artista polonês como referência. Proporei assim alguns caminhos de abordagem dos conceitos a partir da obra escrita de Grotowski, de Thomas Richards e de Mario Biagini. ${ }^{1}$ Buscarei analisar certas definições correntes, apon-

Tatiana Motta Lima é atriz, professora de Interpretação da UNI-RIO e doutoranda do Programa de Pós-Graduação em Teatro da mesma Universidade.

1 Thomas Richards e Mario Biagini são, respectivamente, o diretor geral e o diretor associado do Workcenter of Jerzy Grotowski and Thomas Richards, localizado em Pontedera, Itália. No Workcenter se desenvolvem, atualmente, pesquisas em torno da "arte como veículo" (desde 1986) e em torno do "Project The Bridge: Developing Theatre Arts". No projeto "The Bridge", intenta-se, através do artesanato ligado às artes performáticas, estabelecer uma ponte entre a "arte como veículo" e o teatro. One Breath Left, 
tando o que vejo como problemas e deixando algumas questôes.

Um primeiro problema que localizo no tratamento dado ao vocabulário grotowskiano é que esse vocabulário aparece, muitas vezes, separado das investigações às quais esteve relacionado. ${ }^{2}$ Essa operação de retirada dos termos da sua relação com experiências práticas específicas pode gerar algumas incompreensóes. A mais problemática delas é aquela que toma as idéias de Grotowski como fazendo parte de um conjunto homogêneo e sem contradições. Ora, Grotowski rechaçou, abandonou, transformou, renomeando ou não, vários de seus conceitos no curso de sua investigação. E não estou falando apenas das mudanças ocorridas nos períodos que o próprio Grotowski classificou como as diferentes fases de sua vida artística ${ }^{3}$ - 'A arte como apresentação', 'o parateatro', 'o Teatro das fontes' e 'A arte como veículo' ${ }^{4}$-, mas, principalmente, das transformações pelas quais passaram os conceitos (e as práticas) dentro de cada uma dessas fases.

Essa homogeneidade pressuposta dos textos impede, inclusive, que se perceba uma das características mais interessantes de Grotowski enquanto 'teórico': o fato dele realizar, quase a cada novo texto, um efetivo diálogo com seus próprios textos anteriores; retomando, de ma- neira explícita ou não, seus próprios conceitos para criticá-los, transformá-los e mesmo reexplicá-los, seja à luz de novas experiências realizadas em sala de trabalho, seja ainda à luz do que percebeu como possíveis 'erros' de leitura aos quais seus conceitos teriam sido submetidos.

Uma leitura homogeneizadora acaba, assim, por reunir, em uma mesma formulação e sob um mesmo nome, conceitos diferentes provenientes de experiências diversas e, o que é pior, conceitos que às vezes estão, na própria obra de Grotowski, em oposição. Essa operação dá origem a conceitos 'Frankenstein' que definitivamente não nos fazem avançar.

Ao 'ler' Grotowski é preciso estar atento também ao fato de que, em certos momentos, ele mantém termos já utilizados anteriormente, mas altera consideravelmente seu sentido. Assim, o que ele entende por 'forma' em um certo momento pode ser bastante diferente do que preconiza em um outro. Isto se explica porque o termo 'forma' não está solto em sua obra, mas ligado à sua trajetória de investigação e ao diálogo que realiza com seus leitores. Não devemos, portanto, inferir que palavras semelhantes designem conceitos semelhantes. Entre os termos e os conceitos há todo um trabalho que precisa ser realizado. ${ }^{5}$

Dies Ira e Dies Ira: My Preposterous Theatrum Interioris Show foram as obras produzidas, até agora, por esse projeto. Richards e Biagini, além de seu trabalho prático, dão conferências, têm livros, artigos e/ou entrevistas publicados.

2 Não estou dizendo que os textos de Grotowski respondam, imediatamente, às mudanças ocorridas na sua investigação prática, e nem mesmo que sejam todos eles testemunhos da trajetória dessas investigações. De fato, existem, ainda que em número reduzido, textos nos quais ele revela mais desejos do que de práticas efetivamente experimentadas. Não estou também afirmando que se chegará a compreender totalmente as investigações práticas de Grotowski somente através do estudo de seus textos. Saliento apenas que, mesmo se a relação entre 'texto' e 'cena' não é direta, não há dúvida que, no esforço de tecer a trama dessa relação, nos aproximamos de forma mais pertinente tanto dos conceitos quanto das práticas de Grotowski.

3 Ver a parte IV do texto "De la compagnie théâtrale à l'art comme véhicule", texto de Grotowski incluído no livro "Travailler avec Grotowski sur les actions physiques" de Thomas Richards.

4 Uma introdução à "Arte como veículo", em português, pode ser encontrada em Motta Lima (1999) e em Calvert (2002). 
Os conceitos de 'estrutura' e 'espontaneidade' foram escolhidos como o centro da investigação deste artigo. Além de serem conceitos nucleares na obra de Grotowski que, portanto, dialogam com inúmeros outros, eles permitem também que percebamos mais claramente os problemas de uma leitura homogeneizadora. Permitem, em outras palavras, que coloquemos rapidamente o dedo na ferida.

Tentarei, por diferentes caminhos, 'cercar' a terminologia, aproximar-me dos conceitos por uma via que aceitará os paradoxos e as dúvidas e que não espera 'dar conta' do todo; e, embora relacione terminologia e processos artísticos na obra grotowskiana, não seguirei todo o tempo uma temporalidade seqüencial na exposição do problema.

As palavras 'estrutura' e 'espontaneidade' e seus, por vezes, respectivos sinônimos, 'partitura' e 'forma', para uma e 'vida' e 'organicidade' para outra, quando aparecem no dia-a-dia de trabalho de um ator que se interessa pela pesquisa de seu ofício, estão, muitas vezes, revestidas de um certo peso moralizante. São entendidas como obrigações do bom ator que, assim, teria que encontrar o mais rápido possível os meios (e métodos) de realizá-las em sua prática. $\mathrm{O}$ 'devemos ter uma partitura' e o 'devemos estar vivos em cena' acabam, então, escondendo o que seriam, talvez, as questôes mais interessantes. Questões que não se submetem a procedimentos produtivos e nem a métodos estan- ques e que dizem respeito à investigação prática incessante do que vem a ser essa 'vida' e essa 'estrutura', de qual a sua inter-relação (já que se trata de um binômio) e sua importância.

Em o "Teatro Morto", ${ }^{6}$ Brook falava de um teatro que está o tempo todo andando sob um fio de navalha estendido entre a mecanicidade e a experiência 'viva'. Aquilo que é mecânico, morto, não fixaria casa apenas em alguns tipos de teatro, em alguns atores ou métodos de aprendizagem. Nem o que é vivo estaria seguro de uma vez por todas quando optamos por um certo tipo de fazer teatral mais investigativo. Brook, em vez de conceituar uma certa noção de teatro, acaba, ao contrário, por espraiar o 'morto' e o 'vivo' por todos os lugares e momentos, convidando-nos a uma busca incessante pelo segundo. Se aceitarmos sua concepção, o teatro que não se quer 'morto' terá que trabalhar sob a égide dos ajustes e transformaçōes, sob a égide de um certo tipo de instabilidade. E é só em estreita relação com essa busca por um teatro 'vivo' que podemos nos aproximar dos conceitos de 'estrutura' e 'espontaneidade' em Grotowski.

O que seria, então, uma 'estrutura', tendo em vista essa busca? O que se estrutura? Quando? Por quê? Ao responder a essas perguntas e ao propor uma certa via de leitura do binômio 'estrutura/espontaneidade', corre-se o risco de, no desejo de explicar, acabar por esterilizar os conceitos. Impus-me, então, duas regras que

5 Um outro problema para 'ler' Grotowski - que também está relacionado com a confusão entre termos e conceitos - é a interseção que tem sido feita, de maneira um tanto apressada, entre sua obra e a de Eugenio Barba. Efetivamente, Barba tomou parte, principalmente nos primeiros anos, do trabalho de Grotowski: foi seu assistente de direção nas montagens de Akrópolis e na primeira versão de Dr. Faustus, e auxiliou na divulgação da obra do artista polonês, tendo editado, pelo Odin Teatre, em 1968, o livro "Em Busca de um Teatro Pobre'. Além disso, Barba se manteve em contato com as pesquisas desenvolvidas por Grotowski ao longo das fases de trabalho do artista polonês. Mas esses fatos não nos permitem inferir que a terminologia e as práticas 'grotowskianas' devam ser vistas como referidas àquelas de Barba, ou vice-versa. Creio mesmo que fazer atritar os conceitos de Barba e Grotowski referidos, às vezes, a uma terminologia semelhante ajudaria a perceber diferenças fundamentais entre essas duas obras e a localizar melhor a contribuição de cada um desses artistas.

6 Primeiro capítulo do livro "O Teatro e seu Espaço”, de Peter Brook. 
pretendo seguir o mais fielmente possível. A primeira é de que os conceitos, se aparecerem, serão o resultado - esperado, mas não evidente de um processo de indagação e crítica, processo em curso muito antes da escrita deste texto. Busca-se, então, trazer no bojo dos conceitos, não um entendimento estéril ou erudito, mas uma inquietação e instabilidade àquilo que pensávamos já ter entendido ou realizado. A segunda regra é a de não trabalhar com vistas à 'dicionarização' mas, num vaivém entre as experiências práticas e a terminologia, ver como um artista filia certas experiências a conceitos na tentativa de nomear aquilo que foi realizado e, ao mesmo tempo, de dialogar com outros que estão do lado de fora das práticas experimentadas. Creio que esse procedimento ajudará na formulação de perguntas dirigidas à nossa própria prática artística.

Seguirei a trajetória do binômio 'estrutura/espontaneidade' no percurso artístico de Grotowski, concentrando-me nos seguintes períodos: entre os anos de 1959 e 1969 (a chamada 'fase teatral') e no período relacionado às investigações do Workcenter of Jerzy Grotowski, que foi inaugurado em 1986. Para analisar esses últimos anos, utilizarei textos, entrevistas e conferências de Richards e Biagini, alguns deles realizados mesmo após a morte de Grotowski, em 1999.
O artigo está dividido em quatro seçoes: as três primeiras referem-se a três 'momentos' de conceituação do binômio na 'fase teatral' e a última investiga o binômio a partir de certas noções utilizadas no Workcenter. ${ }^{7}$

\section{Seção I}

Nos seus primeiros textos, ${ }^{8}$ ao traçar um paralelo entre 'teatro' e 'ritual', Grotowski fazia um elogio da 'artificialidade'. No ritual, ele identificava um 'sistema de signos' abreviado, definido a priori, e, portanto, convencional, artificial. Também a 'teatralidade' se distinguiria da vida de todo dia por ser produtora de signos. Grotowski fazia uma diferença entre o que chamava de 'lógica da forma', justificada pelas leis da 'teatralidade' e baseada na construção de signos, e 'lógica da vida corrente' que, não sendo estruturada, não seria, portanto, artística (Grotowski, 2001 [dez. de 1960], p. 42-3). ${ }^{9}$ Assim, o teatro, naquele momento, era definido como um espaço de construção, de 'estruturação' e de 'artificialidade'.

Essa 'teatralidade', nos primeiros espetáculos, era buscada eqüitativamente em todos os elementos da mise-en-scène, não havendo nenhuma ênfase particular sobre o trabalho do ator. Foi só em Shakuntala, ${ }^{10}$ quarto espetáculo

7 Estarei analisando textos de Grotowski, Richards e Biagini, escritos em diversas línguas. Para facilitar a leitura deste artigo, optei por traduzi-los, responsabilizando-me, assim, por possíveis incorreçôes. Também farei a tradução de outros textos em língua estrangeira que venha a citar ao longo do artigo.

8 Refiro-me, principalmente, aos textos "Giochiamo a Siva" e "Farsa-Misterium", ambos de 1960, e "La Possibilità del Teatro" que, até a publicação do livro "Il Teatr Laboratorium di Jerzy Grotowski 19591969", em 2001, estavam inacessíveis ao leitor não familiarizado com a língua polonesa. Além disso, "Farsa-Misterium" e "La Possibilità del Teatro" faziam parte do arquivo pessoal de Ludwik Flaszen, cofundador do Teatro das 13 Fileiras e não haviam sido publicados nem mesmo na Polônia.

9 Utilizarei colchetes [ ] para informar ao leitor a primeira data referente à citação utilizada, seja a data da primeira publicação, seja a data da entrevista ou conferência que esteve na origem dessa publicação.

10 Shakuntala, antigo drama erótico indiano escrito por Kalidasa, estreou em 13 de dezembro de 1960. Antes disso, o Teatro das 13 Fileiras, inaugurado em 1959, já tinha apresentado Orfeu de Jean Cocteau, Cain de Byron e Mistério Buffo de Mayakovski. 
de Grotowski à frente do então Teatro das 13 Fileiras, que aquela 'artificialidade' começou a ser trabalhada através da 'partitura de signos vocais e corporais do ator': “... Aparecia a partitura do ator, minuciosa, matematicamente exata [...] O corpo-voz" (Flaszen, 2001, p. 24). Nesse momento, apareceu também a noção de um 'ator-feiticeiro', construtor de signos que provocariam associações no psiquismo da platéia; ${ }^{11}$ signos sonoros e corporais fixados precisamente em uma 'partitura'. Como um feiticeiro, o ator deveria conhecer e controlar seus instrumentos, seu corpo e sua voz, de maneira a que pudessem fugir da esfera do cotidiano e, aventurando-se em posições, gestos e entonações inusuais, causar impacto profundo na imaginação do espectador.

Nesses primeiros anos da década de 1960 , as palavras 'habilidade', 'efeito', 'truque' eram utilizadas de maneira elogiosa por Grotowski quando referidas ao trabalho do ator, ${ }^{12}$ pois o artista entendia que, para ser produtor daqueles 'signos', o ator deveria, assim como o feiticeiro, possuir um arsenal de instrumentos a serem utilizados quando necessário. Não é de se estranhar, portanto, que exatamente à época de Shakuntaka se inicie o treinamento vocal e corporal dos atores do Teatro das 13 Fileiras. Esse treinamento, ao contrário do que ocorrerá um pouco mais tarde, estava extremamente vincu- lado tanto às necessidades específicas de cada espetáculo quanto à instrumentalização do ator, que deveria ser capaz de, com seu corpo e voz, sair das esferas da expressividade cotidiana e aventurar-se na produção dos 'signos', entendidos como gestos e sons capazes de tocar o "inconsciente coletivo"13 dos espectadores.

Nesse primeiro momento, a 'partitura' era, portanto, um conjunto de signos vocais e corporais, repetidos pelo ator habilidoso de maneira precisa e, mesmo, como pontua Flaszen, matemática. Os 'signos' se diferenciariam da gestualidade cotidiana, instaurando uma 'lógica da forma' capaz de afetar ao mesmo tempo íntima e coletivamente a comunidade de espectadores. Podemos perceber, assim, que o alvo mais evidente da 'partitura' era, nesse momento da trajetória artística de Grotowski, a platéia: buscava-se impactá-la através dos signos produzidos.

Grotowski fez, explícita ou implicitamente, em inúmeros textos posteriores, críticas a esse período de sua investigação, ou pelo menos a alguns dos pressupostos de trabalho presentes naquele momento. Uma facilmente localizável é aquela que se refere à busca, pelos atores, de um arsenal de habilidades e, também, de um virtuosismo técnico. Segundo Grotowski, visando 'habilitar-se' para seu trabalho, o ator estaria, muitas vezes, reforçando a divisão entre ele

11 O gesto ou entonação do ator estariam associados a um 'modelo' de gesto ou encantação, "associado(s) a qualquer coisa que tenha um significado universal [...]. Penso em uma arte do ator que - através da alusão, da associação, do aceno com o gesto ou com a entonação - se refira aos modelos formados na imaginação coletiva. " (Grotowski, 2001 [fev. de 1962], p. 78).

12 "[...] aquilo que é artístico, que é arte, é artificial [...] como uma demonstração de habilidade, pode ser examinado como puro efeito (físico ou vocal) [...] são possíveis e mesmo convincentes os 'truques' do ator que consistem em contrapor a palavra e o movimento [...]" (Grotowski, 2001[fev. de 1962], p. 77-78).

13 Grotowski define, assim, inconsciente coletivo: “[...] não significa aqui (diferentemente da escola junguiana) uma qualquer psiquê 'supra individual', mas funciona como uma metáfora operativa; tratase da possibilidade de influir sobre a esfera inconsciente da vida humana numa escala coletiva" (2001[fev. de 1962], p. 53). 
mesmo e seu organismo. Produzir-se-ia, assim, um corpo 'domesticado', não 'liberado' para as possibilidades do 'processo criativo'. ${ }^{14}$

Pode-se inferir que ao criticar uma certa relação do ator com o seu corpo e sua voz, relação que geraria entraves ao processo criativo, Grotowski estava, ao mesmo tempo, criticando a 'partitura' que tinha sido estruturada com base nessa mesma relação. Isso ficará mais evidente quando analisarmos, mais adiante, os novos conceitos de 'partitura' surgidos entre Shakuntala e os últimos anos da década de 1960.

Para finalizar essa primeira seção, cito uma crítica contundente que Grotowski fez, em texto de 1968, à Shakuntala, crítica que revela tanto a direção do trabalho realizado no espetáculo, quanto aquilo que o artista percebeu como erros que foram posteriormente retificados.

[...] Nós montamos um espetáculo, Shakuntala de Kalidasa, onde investigamos a possibilidade de criar signos no teatro europeu. [...] O espetáculo efetivamente era construído com pequenos signos gestuais e vocais. [...] O espetáculo foi realizado, era uma obra singular, dotada de um certo poder de sugestão. Mas eu percebi que era uma transposição irônica de todos os estereótipos possíveis, de todos os clichês possíveis; cada um desses gestos, desses ideogramas propositalmente construídos era, no fundo, o que Stanislavski chamava: 'clichês gestuais'; não havia, na verdade, 'eu amo' com a mão sobre o coração, mas, definitivamente, se reduzia a algo parecido. Tornou-se claro que não era este o caminho (Grotowski, 2001 [out. de 1968], p. 144-5).

Quando Grotowski comparava os 'signos' produzidos em Shakuntala com aquilo que
Stanislavski nomeou 'clichês gestuais', podemos deduzir, para o tema deste artigo, que os atores mantinham com as suas 'partituras', apenas um vínculo 'formal'. Quero dizer com isso que as formas finais não eram influenciadas pelo fluxo de imagens ou de açôes atorais, mas podiam ser descritas quase como fotografias reproduzidas a posteriori por músculos bem treinados que desconheciam - porque não reatualizavam - os sentidos das imagens que reproduziam. Os clichês, nesse caso, poderiam também estar relacionados a uma certa fixidez da atenção dos atores: preocupados em reproduzir as 'formas musculares' que haviam sido estabelecidas, eles acabavam impedindo que as transformações inerentes à dinâmica da 'vida psicofísica' participassem da 'partitura'. Se observarmos as fotos do espetáculo Shakuntala, ${ }^{15}$ podemos perceber essa gestualidade da qual falava Grotowski: os atores estão como que parados em certas poses ou posições inusuais.

\section{Seção II}

Até Shakuntala, o conceito de 'partitura' ou de 'forma' não se relacionava com o conceito de 'espontaneidade'. Essa relação só começa a aparecer nos textos de Grotowski a partir de 1962, e, inicialmente, de maneira tímida. A primeira referência está, salvo engano, no texto "La Possibilità del Teatro", no qual Grotowski dizia que, a partir de um aprendizado prático, teria chegado à conclusão que "a escola de 'viver o papel' ou seja, a escola de Stanislavski - tem um pouco de razão", que à forma era necessário aliar o que chamava, naquele momento, de "empenho interior", "intenção consciente", ou "associações íntimas" do ator (2001[fev. de 1962], p. 77).

14 Ver o texto de Grotowski "Los Ejercicios”, na Revista Máscara de 1993. Esse mesmo texto está publicado, em italiano, no livro "Il Teatr Laboratorium de Jerzy Grotowski 1959-1969", de 2001. Acredito que esse seja um texto fundamental para analisar a noção de 'corpo' em Grotowski.

15 Podem-se ver essas fotos nos livros "Le Théâtre Laboratoire", de 1979 e "Jerzy Grotowski: Zródla, inspiracje, konteksty", de 1998. 
Grotowski afirmava ainda que esse 'empenho interior' deveria acontecer não só durante o trabalho de 'composição', mas também no momento de realização da 'partitura'. Aqui, ele parece também concordar com Stanislavski quando este opunha à 'arte da representação' a 'arte da vivência". Na primeira, o "viver o papel" ocorria apenas como "preparativo para o aperfeiçoamento de uma forma exterior", seria apenas "uma fase preparatória numa elaboração artística mais ampla”; já na segunda, o 'viver o papel' era considerado "o instante primordial da criação" e, portanto, deveria ocorrer todas as vezes que o ator interpretasse seu personagem, fosse nos ensaios ou nas apresentações ${ }^{16}$ (Stanislavski, 1984, p. 47). ${ }^{17}$

Antes de 1962, não havia, no trabalho de Grotowski, uma relação entre a 'partitura' e aquilo que poderíamos chamar de 'subjetividade', 'pessoalidade' ou 'interioridade' do ator. Foi só a partir desse momento que "processo pessoal" e "articulação formal" (Grotowski, 1987 [1965], p. 15) ${ }^{18}$ começaram a aparecer como duas faces de uma mesma moeda, ainda que essas faces, esses dois pólos do binômio, assumam, com o passar dos anos, diferentes configuraçōes. Nos textos escritos entre 1962 e 1965, já podemos ver algumas dessas configurações. Em "O Novo Testamento do Teatro", 19 de 1964, por exemplo, ainda são fortes - ao menos na terminologia empregada - os ecos das experiências anteriores. Grotowski definia a 'artificialidade' de maneira semelhante àquela que vimos em Shakuntala, como "um problema de ideogramas [...] que evocam associaçôes no psiquismo da platéia”, mas, esse ideograma começava

16 Quando retiramos os termos 'estrutura' e 'espontaneidade' de sua relação permanentemente dinâmica e polar, acabamos também por nos aproximar dessa escola da 'arte da representação'. As experiências sensíveis, imagéticas e relacionais do ator seriam utilizadas para dar vida a certas formas que, quando prontas, necessitariam apenas ser bem realizadas, mas não mais reatualizadas, a partir da relação do ator com o seu ambiente, no momento da sua realização.

17 A diferenciação entre 'arte da vivência' e 'arte da representação' pode ser lida como referida a dois modos distintos de convivência entre as noções de 'estrutura' e 'espontaneidade'. Pode-se encontrar essa diferenciação no capítulo "Quando Atuar é uma Arte" da "Preparação do Ator" de Stanislavski. Para uma leitura mais fidedigna, sugiro o capítulo "Arte de la Escena y Oficio de la Escena" no livro "El Trabajo del Actor sobre si mesmo - Tomo I". A tradução, nesse caso, foi feita diretamente do original russo.

18 Além desses termos, Grotowski também utilizou, à época, entre outros, 'artificialidade', 'composição artificial' e 'disciplinas externas' para o primeiro, e 'autopenetração', 'técnica interior' e 'processo interior' para o segundo. Nessa época, a 'interioridade' do ator passou, paulatinamente, a fazer parte do processo de trabalho, que se modificou inteiramente. Nos ensaios de Dr. Faustus, espetáculo de 1963, Grotowski começou a trabalhar com cada ator individualmente, desenvolvendo procedimentos que dependiam significativamente da relação estabelecida com cada um. $\mathrm{O}$ trabalho do 'ator santo' era entendido como um trabalho de 'confissão', e a cena era construída no embate com as 'associações pessoais', com as vivências de cada ator. $O$ treinamento se tornou cada vez menos vinculado ao espetáculo e passou a ser visto como um lugar de pesquisa íntima do ator, um lugar que acolhia as experiências pregressas do ator, possibilitando também o nascimento de novas experiências.

19 Esse texto faz parte do livro "Em Busca de um Teatro Pobre". Trabalharei com alguns textos desse livro publicado em 1968. Advirto o leitor de que o livro não será pensado como um todo orgânico, isento de contradições. Os textos, entrevistas e relatos que o compōem foram escritos em anos diferentes e, assim, trabalham com conceitos referidos a experiências e diálogos diversos. Cada capítulo do livro será, portanto, investigado como uma unidade em separado, mas que, é claro, ilumina outra unidade por continuidade, oposição ou reconfiguração. 
a ter uma função também junto às "motivações escondidas do ator", transmitindo-as instantaneamente ou lutando contra elas (Grotowski, 1987[1964], p. 33-4). Nesse mesmo texto, Grotowski também revelava procedimentos que parecem semelhantes à busca pelos 'signos ocidentais' realizada em Shakuntala, como o procedimento de estabelecer, ao buscar a 'artificialidade, "uma miniatura de tabela para cada parte do nosso corpo". Porém, essa rigidez nas "disciplinas externas" é apresentada como um par exigido à absorção "no que está escondido dentro de nós” (Grotowski, 1987[1964], p. 34). O novo conceito de 'forma', que agora fazia parte de um binômio, demandava a modificação de antigas noçōes. Grotowski mantinha parte da terminologia anterior, - como o termo 'artificialidade' - mas, começava a reconceituá-la, a retirá-la daquele contexto de investigação apresentado na primeira seção deste artigo.

No artigo "Em Busca de um Teatro Pobre", de 1965, Grotowski assinalava, ainda, uma outra qualidade do binômio: a "tensão tropística" entre as unidades que o compunham. Esta tensão esteve, a partir de então, todo o tempo presente na sua obra escrita. Grotowski dizia que "a forma é como uma sedutora armadilha à qual o processo responde instantaneamente, contra a qual luta" (1987[1965], p. 15; grifo $\mathrm{meu}$ ). Richards, trinta anos depois, falava desse mesmo "paradoxo do métier do ator", pois, afirmava que era somente a partir da luta de duas forças opostas, que nomeou 'forma' e 'fluxo da vida', que o equilíbrio da vida cênica poderia aparecer (Richards, 1995, p. 50). Voltaremos, mais adiante, a essa noção. Por hora, ressalto apenas que, para Grotowski, naquele momento, não havia uma "contradição entre a técnica interior e o artifício". Ele acreditava que o 'processo interior' do ator não só suportava a 'artificialidade', como necessitava dela para existir e expandir-se. Em momentos chaves, a 'interioridade' amalgamava-se com o 'artifício': "O homem em um estado espiritual elevado não se comporta 'naturalmente', usa símbolos ${ }^{20}$ articulados ritmicamente...” (1987[1965], p. 15).

À guisa de conclusão desta seção, creio que podemos entender melhor os termos daquele binômio, nessa época específica, se aceitarmos que navegavam entre pelo menos dois eixos conceituais. Por um lado, a 'forma' estava relacionada ao espectador; buscava-se, através dela, afetar seu psiquismo e transmitir-lhe as motivações secretas do ator. Por outro lado, a 'forma' também operaria - e seria mesmo fundamental - no âmbito do trabalho do próprio ator, já que ela suportaria, reforçaria e expandiria o 'processo interior'.

Outra especificidade que percebo no binômio 'espontaneidade/estrutura', nos textos datados de 1963 a 1965, é sua similaridade com o que nomeamos classicamente de 'interno/externo' ou de 'conteúdo/forma'. Embora proponha entrelaçamentos interessantes - paradoxais, não-lineares - entre esses dois pólos, Grotowski acabava trabalhando com a imagem de um certo 'interior' do ator que estaria encoberto (talvez informe, desencarnado) esperando para ser 'penetrado', e oferecido ao 'exterior' de maneira estruturada. ${ }^{21}$ Como veremos adiante, esse

20 Grotowski, ao explicar sua noção de 'símbolo', afastou-a dos "símbolos hieroglíficos do teatro oriental". Dizia que, no teatro oriental, os símbolos eram "inflexíveis, como o alfabeto", mas que, no seu trabalho, eles eram a "articulação da psicofisiologia particular do ator" (1987[1965], p. 21). Nesse mesmo texto, mais adiante, 'símbolo’ se apresentava quase como sinônimo de 'impulso': Grotowski dizia procurar "a quintessência dos símbolos pela eliminação daqueles elementos do comportamento 'natural' que obscurecem o impulso puro" (1987[1965], p. 16; grifo meu). Por essas citações, pode-se perceber a diferença entre esse momento e aquele de Shakuntala. Em 1965, a busca era 'psicofísica': noção de 'oganicidade' começava a fortalecer-se. 
binômio foi trabalhado de maneira diferente nos anos seguintes, principalmente após a experiência do espetáculo $O$ Príncipe Constante.

Em texto do início da década de 1970, Grotowski parecia criticar exatamente aquela dicotomia de seus textos (e, quem sabe, também as leituras de sua obra que se aprisionavam nesse período e nessa nomenclatura) quando criticava a expressão 'se abrir':

"Nós caímos todos em tentação, e também eu, por essa palavra mágica, 'se abrir'. Mas, a partir do momento que nós dizemos 'se abrir' nós caímos na cova dessa tradição milenar que, a despeito da todas as suas vitórias, apesar de toda sua fecundidade, nos mutila: aquela que diz que o homem se divide entre o que é interior e o que é exterior, o intelecto e o corpo, etc. $\mathrm{Na}$ verdade, quando dizemos 'se abrir', queiramos ou não, dizemos que em nós, bem no fundo, há algo que é preciso deixar sair e oferecer aos outros; que o interior e o exterior existem como duas coisas distintas [...] um pouco para evitar agir com todo o seu ser [...], inteiramente" ([dez. de 1970] 1973, p. 10).

\section{Seção III}

Para continuar a investigação sobre o binômio 'estrutura/espontaneidade' através das investigações práticas do Teatro Laboratório, é importantíssimo referirmo-nos aos textos escritos entre 1966 e o final da década de 1960,22 textos sem dúvida ligados a algumas descobertas feitas ao longo do trabalho sobre os espetáculos $O$ Príncipe Constante 23 e Apocalipsys cum Figuris. ${ }^{24}$

Existe um 'conceito-chave'25 na leitura desses textos, conceito que se relacionava com

21 Estou sintetizando as experiências riquíssimas desse período que gerou espetáculos como Akrópolis e Dr. Faustus. Isso se faz necessário no âmbito de um artigo, mas preciso ressaltar que o período entre 1962 e 1965 foi um período de transformações profundas e inúmeras descobertas tanto no âmbito do trabalho do ator, como naquele da relação com o espectador.

22 No livro "Em Busca de um Teatro Pobre", penso em "O Discurso de Skara", "O Encontro Americano", "A Técnica do Ator" e em "Ele não era inteiramente ele". Penso ainda, em alguns textos do final da década de 1960 - principalmente "Teatro e Rituale" - nos quais Grotowski fez um certo balanço de sua trajetória teatral. Outros textos importantes para entender essa época estão no livro "The Grotowski Sourcebook", de 1997.

23 O Príncipe Constante estreou em 1965, tendo sido apresentado até 1968. Embora já se possa perceber a influência das experiências realizadas nesse espetáculo em alguns dos textos datados de 1964/1965, acredito que elas nortearão mais fortemente textos e entrevistas posteriores, de 1966/1967.

24 Apocalipsys estreou em fevereiro de 1969 e continuou sendo apresentado e transformado durante o período 'parateatral' do Teatro Laboratório.

25 Talvez o conceito mais importante do período seja 'ato total', termo cunhado por Grotowski para nomear a experiência de Cieslak em O Príncipe Constante. A noção de 'ato total' possibilitava considerar um amálgama entre aquilo que é físico - biológico, instintivo - e aquilo que é espiritual: "É como um degrau para o ápice do organismo do ator, no qual consciência e instinto estejam unidos" (Grotowski, 1987[1967], p. 180). Além disso, para o tema desse artigo, o 'ato total' também é um conceito importante, pois que originado pela "conjunção de opostos [espontaneidade e disciplina]" (Grotowski, 1987[abr. de 1967] p. 99). Optei, entretanto, por trabalhar sobre o conceito de 'contato' porque creio que essa nomenclatura pode ser mais imediatamente dirigida às experiências práticas. $\mathrm{O}$ conceito de 'contato' foi trabalhado por Grotowski, principalmente, em situaçôes onde ele estava en- 
inúmeras transformaçōes práticas ocorridas no Teatro Laboratório e que, sem dúvida, nos ajudará a entender a trajetória do binômio que estamos investigando. $\mathrm{O}$ conceito a que me refiro é o 'contato'. Existem várias camadas de compreensão desse conceito que é só aparentemente simples. Inicialmente, vamos aceitar que, de forma geral, estar 'em contato', significa estar 'em relação com', 'reagir a', 'responder a'.

Grotowski disse ter descoberto esse conceito "na base de um problema completamente objetivo e técnico" (1987[dez. de 1967], p. 201). Um problema que poderia ser formulado mais ou menos assim: o ator corria o risco de compreender aquele 'processo interior', aquele trabalho de 'auto-revelação' e de 'amadurecimento', como um trabalho que se realizaria a partir dele e que seria voltado, também, para ele mesmo. Esse seria, para Grotowski, um ator concentrado "no elemento pessoal como um tipo de tesouro" [...], "procurando a riqueza de suas emoções", um ator que apenas estimularia artificialmente o processo interno, um ator imerso em uma espécie de "narcisismo" (1987[jan. de 1966], p. 191). Para fugir desse problema, Grotowski afirmava que o ator, a fim de se realizar, não deveria trabalhar para si mesmo, que "penetrando em sua relação com os outros - estudando os elementos de contato -, o ator descobrirá o que está nele" (1987[dez. de 1967], p. 202).

'Estar em contato' significava, concomitantemente, perceber o outro e reagir intimamente de acordo com essa percepção; significava também que era no presente, agindo e reagindo no aqui e agora das relaçóes, que se poderia trabalhar com aquilo que dizia respeito ao âmbito da memória, das associações ou das aspirações e desejos.

Ouakinine ${ }^{26}$ chamava o ator, nessa pesquisa, de "l'acteur Proust". Para ele, a motivação criativa do ator corresponderia à 'memória involuntária' de Proust. $\mathrm{O}$ processo poderia ser descrito assim: o ator está em cena, realizando suas ações. Em um dado momento, uma dessas ações abre a porta das associaçôes, das memórias do ator. Essa associação transforma a totalidade psico-corporal do ator: sua voz, seus gestos, sua expressão são modificados, determinados por essa associação pessoal. $\mathrm{O}$ ator, então, não fica absorvido pela lembrança despertada (o que o levaria, segundo Ouakinine, a ficar "ausente" ou "em outro lugar"), mas reage, a partir daquele comportamento/memória, no espaço/ tempo da própria improvisação, e essa 'reação' estimula seu(s) companheiro(s) de cena. $\mathrm{O}$ ator não fica mergulhado em 'vivências íntimas', mas as percebe como reações dirigidas ao outro, deslocadas espacialmente na direção do outro.

O contato pressupunha, portanto, uma relação concreta com o espaço: é em direção ao outro (aos outros, ao Outro), em termos de espaço físico, que a reação pode se dar. Nesse sentido, o conceito de 'contato' não inclui apenas os atores que se relacionam, mas também o 'espaço' onde acontecem essas relações. $\mathrm{O}$ espaço é, ao mesmo tempo, percebido geométrica e 'existencialmente'. Ele direciona e orienta as relações, ao mesmo tempo em que é direcionado e orientado por elas. Isso pode ficar mais claro

volvido com a pedagogia teatral - em conferências ou entrevistas realizadas após estágios práticos, por exemplo - e isso facilita o approch com o conceito. Além disso, o conceito de 'contato' iluminará a noção de 'ação física' que apresentarei na seção IV.

26 Ouakinine chegou ao Teatro Laboratório em janeiro de 1966. Após um ano de estágio, Grotowski solicitou que ele reconstruísse o roteiro de $O$ Príncipe constante. Ouakinine fez, então, uma série de 90 desenhos que descreviam o desenrolar do espetáculo. Posteriormente, em 1970, ele preparou o volume I da coleção "Les Voies de la Création Théâtrale", inteiramente dedicado ao espetáculo O Príncipe Constante. 
através de uma citação de Grotowski sobre trabalho com o que chamava de "companheiro imaginário": 27

[...] Esse companheiro imaginário deve ser fixado no espaço desta sala real. Se não se fixar o companheiro em um lugar exato, as reaçôes permanecerão dentro da gente. Isto significa que vocês se controlam, sua mente os domina e vocês se movimentam para um narcisismo emocional, ou para uma tensão, um certo tipo de limitação (1987 [jan. de 1966], p. 187).

Para finalizar o conceito de 'contato', mas sem a pretensão de ter conseguido dar conta de todas as suas camadas e variáveis, é necessário também ressaltar sua vinculação à noção de um "companheiro seguro". ${ }^{28}$ Esse seria, segundo Grotowski, um "outro ser humano, que pode realizá-lo [a cada ator] e compreendê-lo absolutamente. [...] Alguém por quem se procura. [...] Este ser humano [...] não pode ser definido [...] precisamos apenas dizer-lhe [ao ator]: "Vocês têm de doar-se totalmente". E muitos atores compreendem" (Grotowski, 1987 [jan. de 1966], p. 202-3). A 'revelação', para Grotowski, implicava, portanto, em 'contato': é que "não há impulsos ou reações sem contato" (Grotowski, 1987[jan. de 1966], p. 187).
Voltando ao nosso tema, pode-se afirmar que o conceito de 'partitura' estava, naquele momento, totalmente associado ao de 'contato'. Dizia Grotowski: "A partitura do ator consiste dos elementos do contato humano: dar e tomar. Olhe para as outras pessoas, confronte-as consigo, com as suas próprias experiências e pensamentos, forneça uma réplica" (1987[1967], p. 182).

Frente ao conceito de 'contato' não é mais possível definir 'partitura' como uma exteriorização organizada de conteúdos interiores, já que no 'contato' aquilo que está 'dentro' ou 'fora' não pode mais ser tão facilmente separado. Os 'impulsos', as 'associações' e as 'reações' estão firmemente atados à 'corporeidade', ao 'outro', e ao 'espaço'. O que se partiturava, nessa via de trabalho, era, ao mesmo tempo, corpóreo, ${ }^{29}$ relacional (o 'outro' é, em alguma medida, parte do 'eu' ou vice-versa) e projetado espacialmente (o espaço físico é espaço de 'reação' e de 'relação'). Essas instâncias - corporal, relacional e espacial - são também percebidas de maneira amalgamada, só podendo estar divididas teoricamente. Além disso, todas as instâncias apontam para um universo, ao mesmo tempo e paradoxalmente, visível e invisível. O corpo, o outro e o espaço podem acolher, na tangibilidade que lhes é própria, a presença do intangível; podem ser setas lançadas ao desconhecido.

27 Fala-se em 'companheiro imaginário' quando o ator dirige a um ser humano, não presente na sala de trabalho, as suas açōes. As 'associaçōes', compreendidas por Grotowski como relacionadas a "qualquer coisa que aconteceu conosco no passado, ou que poderia ter acontecido, ou ainda que deveria ter acontecido: 'Algo enraizado na vida pessoal, por exemplo, uma necessidade nunca satisfeita' (Grotowski apud Magnat, 2000, p. 12), me parecem ser acionadas na relação com esses 'companheiros imaginários'.

28 Essa noção de 'companheiro seguro' parece também estar presente, ainda que não nomeada por Grotowski, nesse trecho do texto "Jour Saint", de 1970: "Eu sou água, pura, que corre, a fonte então é ele e não eu, esse ao encontro de quem eu vou, frente a quem eu não me defendo. É somente quando ele é a fonte que eu posso ser água vivente". Uma outra referência possível para a noção de 'companheiro seguro' pode ser encontrada no conceito de 'Eu-Tu' de Martin Buber.

29 No sentido de um corpo não subjugado ao pensamento racional, um corpo que não ilustra "um movimento da alma", mas que realiza "esse movimento com o seu organismo" (Grotowski, 1987 [abr. de 1967], p. 97-8). 
Se não compreendemos esse amálgama existente, principalmente após $O$ Príncipe Constante, entre 'eu' e 'outro', 'corpo' e 'associaçôes', 'corpo' e 'outro', acabamos por levar essa falta de compreensão para o conceito (e as práticas) de partitura. Acabamos por produzir uma certa fetichização do corpo e da musculatura como se uma 'forma' 'precisa' e 'repetida' levasse inexoravelmente a uma certa 'vida'. Ora, quando Grotowki afirmava que "as recordações são sempre reaçôes físicas” (1987 [jan. de 1966], p. 187) ou que o ator deveria "pensar com o corpo", ou ainda quando falava no "corpo-memória" ou no "corpo-vida" (2001 [mai. de 1969], p. 196), o que estava em jogo, antes de tudo, era a possibilidade de superação de um modelo que separaria corpo, mente e espírito (valorizando o pensamento racional) em instâncias estáveis, distintas e hierarquizadas. Grotowski criticava também a crença, que considerava ilusória, na existência de individualidades fixas e apartadas, em um modelo que separaria rigidamente aquilo que sou 'eu' do que é o 'outro'. ${ }^{30}$ Ao valorizarmos excessivamente aquilo que é corporal, físico ou ao encantarmo-nos com a possibilidade de encontrar ou doar nosso 'eu' verdadeiro, estático e apartado do 'outro', estamos, pelo menos, fugindo do desafio proposto naquele momento por Grotowski.

\section{Seção IV}

Aqui pretendo saltar, e trata-se de um salto de mais ou menos 30 anos, para alguns textos, sejam de Richards ou Biagini, escritos entre o final da década de 1990 e início dos anos 2000.31 Nesta seção, diferentemente do que fiz ao analisar os dez primeiros anos de trabalho de Grotowski à frente do Teatro Laboratório, não seguirei a trajetória dos conceitos, mas escolherei alguns temas que, pouco trabalhados até agora no artigo, não poderiam ficar de fora de uma reflexão sobre 'estrutura/espontaneidade'.

Em primeiro lugar, exploraremos a noção de 'ação física' que, se já era utilizada há muito por Grotowski, só ganha corpo teórico com o livro At Work with Grotowski on Physical Actions de Thomas Richards, publicado em 1993. Trabalharei, dessa noção, somente o que for necessário para iluminar os conceitos de 'estrutura' e 'vida' utilizados pelos diretores do Workcenter.

Além disso, através de certas respostas de Biagini e de um exemplo de Richards, pretendo refletir sobre a polaridade do binômio, o "conjunctio oppositorum" (Grotowski, 2001 [mai. de 1969], p. 197) 'espontaneidade' e 'estrutura', que Grotowski já havia explorado em seus textos da segunda metade dos anos 60 . Veremos como, frente a essa polaridade, as noções

30 Dizia Grotowski em 1970: "O ato do corpo-vida implica a presença de uma outra pessoa humana, a comunicação dos homens, a comunidade. E mesmo nossas lembranças só são verdadeiramente importantes quando elas nos ligam com um outro, quando elas evocam os momentos nos quais nós vivemos intensamente com os outros. [...] e se com seu corpo-vida vocês forem tocar alguém, seu alguém aparecerá naquilo que vocês fazem. E haverá, talvez, ao mesmo tempo, a presença daquele que está aqui e agora, seu parceiro, e daquele que conta na sua vida e daquele que contará na sua vida - e Ele será um. Veja porque, entre outras coisas, isso não pode contentar-se com a introspecção, com uma atitude fechada sobre si mesmo" (1973[1970], p. 60).

31 Todas as citações de Biagini são retiradas da entrevista "Incontro all'Università 'la Sapienza', de 2000. As citações de Richards são retiradas tanto de uma entrevista inédita que ele me concedeu em 1999, e que integra a sua tese de doutoramento "De l'art comme véhicule", defendida em 2001, na Paris VIII, quanto de minhas anotaçôes feitas no Symposium International ocorrido no Workcenter of Jerzy Grotowski and Thomas Richards em Pontedera, em dezembro de 2000. 
correntes de 'detalhamento' e de 'precisão' de uma dada 'estrutura' ficam problematizadas.

Por último, serão trabalhados os conceitos de 'ajustamento' e de 'inércia' utilizados por Richards. Veremos como esses conceitos iluminam a noção de 'partitura'.

Antes de tudo, é necessário abrir um grande parêntese para apresentar, em linhas gerais, o que Grotowski, no seu "Projeto de Ensino e Pesquisa: Antropologia Teatral", para o Collège de France, ${ }^{32}$ distinguiu como os dois pólos principais do jogo do ator, pólos que, por analogia, ele localizava também nos rituais: o 'pólo artificial' e o 'pólo orgânico'. Essa diferenciação terá, nesse artigo, um duplo papel na medida em que iluminará as seçôes anteriores, oferecendo a elas uma certa conclusão, ao mesmo tempo em que fornecerá uma introdução às questôes que serão desenvolvidas a seguir.

O primeiro pólo, o artificial, ${ }^{33}$ está ligado a técnicas 'artificiais' de jogo, técnicas que, segundo Grotowski, como aquelas descritas por Diderot no "Paradoxo do Comediante", visam unicamente exercer um efeito sobre a percepção do espectador, sem que seja prevista nenhuma identificação por parte do ator nem com o caráter da personagem, nem com a lógica de comportamento ligada ao papel.

O ator estaria trabalhando, nesse pólo, sobre uma estrutura composta de elementos extremamente precisos (herdados, em alguns casos, das gerações precedentes), estaria concen- trado na 'composição' desses elementos. A movimentação do ator está, mesmo se não é assim que a platéia a percebe, separada em pequenos pedaços, havendo como paradas de frações de segundo entre um movimento e o seguinte. $\mathrm{O}$ engajamento pessoal do ator se dá através da distribuição (e mudanças) na quantidade de força muscular e nervosa (Grotowksi a chama de tônus) que ele utilizaria na realização da sua seqüência. Haveria o que Grotowski chamou de um "fluxo de tônus", mas o corpo do ator não entraria, como no "pólo orgânico", em uma "fluidez do movimento" (Grotowski, p. 15). A maestria da execução do ator está, nesse caso, na sua capacidade de se concentrar nos micro-elementos gestuais de uma composição já pré-ordenada.

Grotowski exemplificava esse pólo principalmente através da Ópera de Pequim, mas citava também Meyerhold, além de outros exemplos do teatro clássico oriental: “... os approches 'artificiais' se caracterizariam pela composição bastante estrita das posiçôes corporais (pelas posiçōes e não pelas transições), pela não-identificação com o processo, pelo que poderíamos qualificar de não-espontaneidade" (Grotowski, p. 18).

O outro pólo, chamado de 'linha orgânica', teria como pai fundador Stanislavski. Segundo Grotowksi, para o encenador russo, o ator deveria "construir a personagem como um fenômeno da sua própria vida" (Grotowski, p. 12). As técnicas 'orgânicas' de jogo estariam apoiadas no fluxo contínuo de impulsos. ${ }^{34}$ São

32 O projeto de Grotowski me foi cedido por Mario Biagini, mas parte desse material está acessível na Revista Teatro e Storia, anno XIII, 1998-1999.

33 Grotowski fez questão de dizer que não havia nenhum desmerecimento por esse pólo ao usar o termo 'artificial', ligado, para ele, e como já testemunhamos no início desse artigo, à mesma etimologia da palavra 'arte'.

34 "Seria falso acreditar que esses impulsos pertencem exclusivamente ao domínio físico. Todo 'l'arrièreplan' das experiências humanas, das associações mentais, das lembranças, de uma linguagem não formulada, mas presente como atrás dos pensamentos, tudo isso, e outras coisas ainda, condicionam os impulsos. [...] Se o fluxo de impulsos que precedem as pequenas açōes se libera, o corpo do ator se torna - em seu comportamento - 'orgânico', para utilizar um termo do próprio Stanislavski” (Grotowski, p. 13). 
técnicas nas quais os elementos inter-humano e corpóreo apareceriam em primeiro plano; Grotowski se considerava ligado a esse pólo, mas, de maneira diferente de Stanislavski, teria trabalhado no "campo do comportamento humano ligado às condições extracotidianas [...] onde [...] o aspecto dos impulsos e da organicidade podem se tornar ainda mais marcados" (Grotowski, p. 13).

Embora esses pólos não devam ser vistos, de maneira alguma, como duas possibilidades que se excluem mutuamente e que exigem fidelidade irrestrita, creio que essas 'categorias' utilizadas por Grotowski acabam apontando, também, para duas maneiras de se trabalhar sobre uma 'estrutura'. Nesse artigo, estamos investigando o conceito de 'estrutura' dentro do trabalho de Grotowski. Nessa investigação, o conceito esteve, sem dúvida, mais relacionado, pelo menos a partir de 1962, às chamadas 'técnicas orgânicas de jogo'.

Parece impossível pensar produtivamente a obra e o legado de Grotowski se não localizarmos em suas investigações um forte deslizamento entre 'arte' e 'vida'. O que é, afinal, essa 'linha orgânica', na qual o fenômeno teatral (ou ritual) está relacionado com os processos psicofísicos do atuante, senão esse deslizamento levado às últimas conseqüências? Não existe, portanto, a idéia de um corpo de ator, um corpo da arte, separado ou diferente do corpo do homem/artista, separado de um 'corpo vivo'. Não existe um corpo para servir à cena. Ao contrário, a cena é que serve como espaço potencializador para a 'vida' do corpo.

E mesmo quando Grotowski falava em 'condições extracotidianas', ele não estava falando em um processo de vida submetido às exigências da arte, mas de uma vida 'excessiva', distinta porque mais visível, menos submetida à domesticação, seja do corpo, das relações ou do pensamento cotidianos.
As exigências do artesanato e do métier do ator fazem sentido no trabalho de Grotowski porque (e se) participam dessa potencialização, são necessários a essa não domesticação da 'vida'. Assim, quando pensarmos em 'partitura', por exemplo, não podemos pensar apenas na sua função junto à fruição do espectador, mas como referida a um 'trabalho do ator sobre si mesmo', para usar uma expressão de Stanislavski. É a serviço daquela 'fluidez do movimento', que Grotowski localizava no 'pólo orgânico', que a 'estrutura' irá funcionar.

Nos textos de Richards e Biagini, essa noção de 'estrutura' está, em geral, bastante próxima da noção de 'ação física'. Estruturar um fragmento seria poder organizá-lo através de uma 'linha de açōes físicas'.

As 'ações físicas' dizem respeito àquilo que o atuante faz: “[...] não é somente algo físico. É algo que envolve você todo: a sua carne, mas também o seu pensamento, a sua vida, os seus desejos e os seus medos e, além disso, a sua vontade, as suas intenções (Biagini, 2000, p. 23-24).

O que é mais relevante na 'ação física', para o tema deste artigo, é que essas intençóes não são pensamentos racionais e nem devem ser entendidas de maneira apenas psíquica ou emocional; elas existem também ao nível muscular do corpo. Richards e Biagini já explicitaram, em inúmeros momentos, que "as intenções estão ligadas também a uma orientação da mobilização corporal ('em-tensão', 'in-tencionar' na direção de algo ou de alguém)" (Biagini, 2000, p. 23-4). ${ }^{35}$ As intenções se configuram, portanto, "como um ponto de contato entre um mundo impalpável e um palpável. Uma ponte entre aquilo que desejo e aquilo que faço" (Biagini, 2000 , p. 24). Por esse motivo, por serem também aquilo que 'faço', as intenções podem ser estruturadas e podem servir de âncoras para o ator que quer se reaproximar de um dado fragmento já experienciado.

35 Ver principalmente o capítulo "Grotowski face a Stanislavski: les impulsions” do livro "Travailler avec Grotowski [...]”, de Richards. 
Mas, se "o trabalho sobre as ações físicas visa essencialmente permitir ao ator construir uma partitura física precisa que possa ser reproduzida", esse trabalho busca gerar, ao mesmo tempo, "a cada vez, um novo fluxo de impulsos e de associações no seio do seu organismo [do ator], influindo sobre ele de maneira não predeterminada e não premeditada" (Magnat, 2000, p. 9). Tenho especial apreço pela frase que acabei de citar, pois, ao reunir em uma mesma formulação as idéias aparentemente contrárias de 'reprodução' e de 'não predeterminação ou premeditação', Magnat deixa-nos entrever uma pergunta fundamental ao trabalho de 'estruturação' de um dado fragmento. A pergunta é: de que modo 'estruturar' quando a 'estrutura' visa, ao mesmo tempo, refazer um fragmento, retornar a uma experiência vivida pelo ator, e permitir que essa experiência continue guiando-se (como toda experiência) pelo que é desconhecido, o que não está determinado a priori?

A partir dessa pergunta, pode-se compreender melhor a afirmação de Biagini quando dizia que a 'estrutura' não é a conscientização, por parte do ator, da totalidade do seu comportamento cênico: "O ator é consciente das suas intenções que vão na direção do exterior (intenções que são, talvez, suscetíveis de acordar nele intenções e reaçooes secretas, íntimas, que são a raiz viva, o núcleo fundamental, quente, de seu ato), mas o modo como a intenção passa no corpo através do agir, passa na voz, passa no espaço, passa no partner. Todo esse processo não é plenamente consciente. No momento em que se torna, há o risco de se ter entre as mãos uma forma vazia” (Biagini, 2000, p. 31; grifo meu). É através de uma certa relação entre aquilo do qual o ator é consciente e aquilo que permane- ce sempre desconhecido que podemos, portanto, antever o conceito de 'partitura'.

Podemos concluir que, desse ponto de vista, nem a 'vida' se apresenta sem uma 'estrutura', nem a 'estrutura' pode ser vista apenas como uma série de movimentos que, bem repetidos, poderão fazer com que o ator reencontre, inexoravelmente, a 'vida' da ação.

Gostaria, agora, de olhar a questão da 'partitura' por um outro ângulo, aquele do material que vai ser estruturado. Utilizarei como metáfora para aquilo que desejo pontuar uma entrevista de Grotowski, na qual ele comenta o modo como as personalidades de Gurdjieff e de Ouspenski ${ }^{36}$ se materializavam nos textos de ambos os autores. Segundo ele, todos "os aspectos pretensamente frios", presentes nos textos de Gurdjieff, e que poderiam ser vistos como "um perigo, uma fria manipulação das idéias" (Grotowski, 1997, p. 125) não o eram, pois que friccionavam com um homem extremamente passional. Gurdjieff, para Grotowski, era "como um vulcão" e seus textos estavam numa relação ao mesmo tempo oposta e sustentada por sua passionalidade. Já Ouspenski era, segundo Grotowski, um homem muito inteligente, um intelectual refinado, de modo que quando Ouspenski utilizava e explicava a terminologia gurdjieffiana, desaparecia este aspecto de luta, de contradição entre algo que não quer se submeter a uma estrutura, a uma nomenclatura, e um esforço, por outro lado, de estruturação e organização.

Grotowski não estava, nessa entrevista, falando sobre o binômio 'estrutura/espontaneidade', mas creio que esse fragmento pode iluminar aquela relação de oposição, luta e sustentação entre os pólos do binômio. Metafo-

36 Gurdjieff, místico nascido provavelmente em 1866, começou a compartilhar seus ensinamentos, na Rússia, um pouco antes da primeira guerra mundial. Em outubro de 1922, funda o "Institute for the Harmonious Developement of Man”, em Fontainebleu-Avon, sul de Paris. Morre em 1949. Gurdjieff escreveu alguns livros, entre os quais Life is only real, then, when 'I am'. Ouspenski (1878-1947), filósofo russo, torna-se mais conhecido como um grande estudioso e comentador da obra de Gurdjieff; entre seus inúmeros livros está o In search of the miraculous, publicado postumamente. 
ricamente, o exemplo pode nos fazer pensar também sobre a escolha do material a ser estruturado. Investiguemos esses dois pontos.

Freqüentemente, a idéia de 'partiturar' seduz aqueles que estão envolvidos com o trabalho artístico. Talvez porque a 'partitura' traga a noção de um resultado, de um ponto ao qual se chegou, talvez porque ela pareça oferecer uma certa segurança, na possibilidade de repetição. Mas, o que vai ser 'estruturado'? E quando começar essa 'estruturação'? Creio que essas deveriam ser interrogaçôes permanentes, respondidas de maneira diversa a cada novo trabalho. Diz Biagini:

"Quando, para mim, o rigor, a estrutura, a artificialidade no sentido forte da palavra atingem todo o seu sentido? Quando a força da vida que escorre dentro do ator é forte, quando verdadeiramente nele acontece algo $[\ldots]$ a vida sempre fará resistência a uma estrutura, faz resistência porque quer sair, é maior, é mais plena. [...] Do meu ponto de vista, a armadura da técnica, do artesanato, tem sentido se protege uma carne viva. Sustenta-a: paradoxalmente, como contradizendo-a, dá-lhe força. E defende-a frente ao mundo" (2000, p. 31).

Assim como no exemplo de Gurdjieff, é no embate de forças opostas que se produz uma experiência criativa. Nesse contexto, não faz sentido pensar, então, em 'estruturação' sem que ainda tenhamos, durante os ensaios, levado a efeito experiências que nos interessem a ponto de querermos reencontrá-las e, necessariamente, aprofundá-las em um confronto com a 'estrutura'. Talvez fosse mais interessante trabalharmos com uma certa idéia de desperdício, um menor apego àquilo que produzimos, ou de forma menos utilitária em relação às nossas experiências. Afinal, o que estamos procurando? Sobre qual material nos interessaria verdadeiramente trabalhar?

Também o momento de começar a 'estruturar' deveria ser uma questão. Qual seria o melhor momento? Ou melhor, se sempre existe uma certa 'estrutura', já que o que fazemos não é, como vimos, informe, qual seria a hora de cercar essa 'estrutura' com vistas a revivê-la e aprofundá-la? Richards respondeu a essa questão quando se referiu a entrada de novos 'atuantes' no trabalho do Workcenter:

"O tempo, a etapa de desenvolvimento de uma dada pessoa, é isto que dita a natureza e o tempo de elaboração de uma estrutura. [...] Para descobrir o potencial, às vezes, a pessoa tem necessidade de espaço, ela não tem necessariamente necessidade que você preencha o tempo muito rapidamente com o que você já sabe: ela está procurando o que ela não sabe. Depois de um tempo de trabalho, depois de ter feito descobertas, quando a questão se torna como manter estas descobertas e desenvolvê-las, nós nos encontramos naturalmente face à questão de como tornar a estrutura mais precisa" (2001, p. 263).

Podemos pensar, então, frente à fala de Richards, em 'estruturas' mais 'abertas' ou 'fechadas' que possam acompanhar a maturação de um certo fragmento. O 'detalhamento' da 'estrutura' não nasceria, assim, nem a sua 'limpeza', como puro artefato, mas como uma demanda da própria experiência (ou do atuante que a realiza) que, refinando-se, refina, ao mesmo tempo, sua 'estruturação'. Haveria uma relação estreita entre o número de 'descobertas' feitas pelo atuante e a 'precisão' de um dado fragmento.

Também aqui, não devemos pensar a relação entre 'estrutura' e 'fluxo de vida' como uma relação entre forma e conteúdo: "Nem mesmo na fase inicial, separamos um aspecto formal de um interior: estruturamos quase que exclusivamente intenções e associações, ou talvez deveria dizer impulsos?" (Biagini, 2000, p. 24). E são essas 'intenções' - ao mesmo tempo tangíveis e intangíveis - que vão ficando mais detalhadas.

A 'estrutura' é uma espécie de canalização que configura uma dada experiência e, ao mes- 
mo tempo, traz em seu bojo a possibilidade de aprofundamento dessa experiência que terá sempre, porque experiência, um dado de risco, de desconhecimento, de inconsciência.

Como vimos, construir uma 'estrutura' não é o processo de trazer à consciência a totalidade do comportamento cênico, e sim um processo de construção de âncoras, de pontos de referência que evitam a dispersão, impõem uma direção e, assim, permitem e exigem sempre novas descobertas, desenvolvimentos e 'ajustes'. Richards trabalhou com a imagem de um rio para exemplificar a 'luta' entre 'forma' e 'fluxo da vida':

A força da água descendo da montanha, caindo, pela força da gravidade, em direção ao oceano é enorme. Se a água desce da montanha sem as bordas de um rio, ela vai dispersar-se um pouco aqui, um pouco lá. É preciso que existam margens - que devem também ter sua força, diferente da força da água, para canalizá-la. Assim, a força dessa mesma água, canalizada, torna-se ainda maior e aparece um rio. [...] Não é que a água queira escorrer como rio, não é que as margens garantam o rio, mas são necessários os dois para que o rio possa aparecer. [...] E por que eu digo luta? Por causa da natureza do ponto de encontro - quando eles se encontram, há uma luta: a água cai e ela vai escorrer em muitas direções, mas a presença das margens resiste, se opõe; elas se mantêm firmes para que a água seja canalizada em uma direção precisa. [...] Sem estrutura será sempre uma questão de sorte, e faltará a possibilidade de desenvolvimento (2001, p. 236-7).

Para concluir esta seção, gostaria ainda de comentar uma possibilidade de relação entre um ator e sua 'partitura', como a percebo através de alguns escritos dos diretores do Work- center. O processo criativo não acaba, para eles, no momento em que, depois de longo trabalho, o ator consegue chegar a uma certa 'estrutura' mais detalhada. Não se trata de, a partir desse momento, simplesmente repetir a partitura, mas de 'vivê-la', de novamente passar por uma certa experiência. Então, digamos que o ator organizou, através daqueles pontos de referência, através das intenções e associações, um determinado fragmento. E agora? Como repeti-lo? Como relacionar-se com esse fragmento?

Toporkov ${ }^{37}$ parece estar se referindo a essa questão quando dizia: "Seria errado considerar a ação física só como um movimento plástico que expressa a ação. Não; é uma ação autêntica, logicamente fundada, que persegue uma finalidade concreta e que, no momento da sua execução, se converte em uma ação psicofísica" (Toporkov, 1961, p. 175; grifos meus). Mesmo depois de estabelecida a 'partitura' o ator corre perigo, pois, como disse no início deste artigo, referindo-me a Brook, o 'teatro morto' está, a todo momento, assaltando o trabalho do ator. Como então completar o ciclo? Ou seja, como, partindo de uma experiência, 'partiturá-la' em ações físicas, em pontos de referência, e como, no momento da execução, não privilegiar a forma ou o que foi organizado a priori, mas deixar essa organização ser, tornar-se novamente, uma série de 'açōes psicofísicas'?

Obviamente, não pretendo dar uma resposta a essa questão. Creio que essa resposta só pode ser encontrada na investigação prática de cada ator. Quero apenas levantar alguns pontos de discussão com os leitores.

Percebo que Richards e Biagini pensam a relação do 'atuante' com sua 'partitura' como uma relação extremamente dinâmica. É como se houvesse sempre, e a todo momento, como pontuam os dois artistas, a pergunta: será que é possível realizá-la (a partitura) inteiramente? É

37 Ator que trabalhou junto a Stanislavski quando o encenador, já no final de sua vida, estava investigando o "Método das Ações Físicas". Toporkov escreveu o livro Stanislavskii na repetitsii, no qual fala desse período. 
como se, com essa pergunta, o ator fosse colocado entre a 'estrutura', aquilo que ele conhece, e o momento presente, aquilo que ele é (esse 'ele é' está relacionado à noção de 'contato', e não se refere a uma individualidade essencial e estática). O desafio seria, ao mesmo tempo, não fugir da 'estrutura' nem desse momento presente. A noção que aparece na fala de Richards para dar conta dessa operação prática é a noção de 'ajustamento'. Trata-se de um certo paradoxo. O ator ajusta a 'estrutura' ao momento presente e, porque a ajusta, pode segui-la, já que ela era uma série de 'intençôes' e não um conjunto de 'movimentos'. Se ele simplesmente mantivesse a estrutura sem ajustá-la, ela se tornaria seca, mecânica, uma seqüência de gestos. Por outro lado, se ele a desrespeitasse, como ela é o próprio caminho para uma dada experiência, ele teria se deixado levar, sem rumo. Aqui estamos no cerne da noção de 'ajustamento': um jogo permanente entre estabilidade e dinamismo. Mesmo correndo o risco de errar a estratégia, permitir o ajustamento, quando necessário, parece ser a única forma de realizar a 'estrutura'.

A noção contrária àquela de 'ajustamento' é a de 'inércia', também de Richards. Estar na 'inércia' seria não se permitir lidar com - e mesmo querer bloquear - a dinâmica inerente à experiência 'viva'. Richards falava da 'inércia' como ancorada em uma certa relação que o ator estabeleceria com a passagem do tempo. $\mathrm{O}$ ator estaria tão fortemente identificado com um certo momento experienciado - tenha sido ele bom ou ruim, de um tempo remoto ou de apenas alguns segundos atrás - que não seria mais capaz de seguir a dinâmica da ação, permanecendo como que amarrado ao passado. Assim, impedido (impedindo-se) de entrar em contato com o que está acontecendo no momento, não realizaria os 'ajustamentos' necessários ao desenrolar da experiência criativa.

A 'inércia' pode ser gerada por várias causas: o apego do ator àquilo que funcionou no passado, o seu apego aos erros que acabara de cometer (no sentido de ficar relembrando os erros nos momentos sucessivos da sua ação), o apego do ator ao olhar - positivo ou negativo do espectador. Os exemplos são infinitos.

Richards afirmava também que permanecer na 'inércia' teria relação com o medo daquilo que ainda é desconhecido, do que poderia vir a acontecer. É como se os atores se fechassem em uma certa moldura conhecida e segura e não vissem se (e quando) algo não funciona e precisa ser modificado, precisa ser 'ajustado'.

Há uma parte de nós [...] que adora fixar as coisas; sentimos como se as conhecêssemos, não nos arriscamos mais no desconhecido. 'Eu faço o que eu já conheço'. [...] Essa atitude não aceita a realidade, que é aquela de que nada pode ser exatamente a mesma coisa. É um paradoxo engraçado: a experiência, no ato performático, pode ser quase a mesma, quase exatamente a mesma, mas não é a mesma, do mesmo modo que nada jamais é o mesmo, tudo se transforma continuamente (2001, p. 245).

Frente à complexidade e às variantes desse processo, seria, portanto, impossível dar uma resposta puramente técnica à questão de como repetir uma ação viva. $\mathrm{O}$ processo estaria nas mãos da pessoa que o realiza. As ferramentas teriam que ser criadas e as estratégias inventadas e reinventadas pelo próprio ator a todo e a cada momento de sua cena.

Pequena conclusão:

É necessário compreender que, sim, todas as coisas podem ajudar, mas a chave está na palavra 'podem', talvez porque quando você vai tentar, você não vai aplicar um dogma, ou uma crença, mas será algo que você está testando, que você experimenta, que você procura. [...] Você tem o 'talvez' e o 'pode' quando se aproxima do que chamaríamos de estratégia ou técnicas; você está acordado e pode julgar por si mesmo (Thomas Richards).

A investigação do binômio 'estrutura/espontaneidade' coloca em questão certas leituras que parecem ter ficado coladas ao nome de 
Grotowski. Creio que, frente a esses conceitos, não é mais possível a classificação de seu teatro como um 'teatro físico'. Também torna-se difícil sustentar uma imagem de subjetividade - do ator - estática e interior que revela e doa sua 'essência' para o mundo. Em Grotowski, pelo menos após meados da década de 1960, quando a subjetividade tem lugar, ela é percebida em fluxo, em dinamismo, enraizada em um 'corpo-vida', onde 'corpo', 'outro', 'espaço', 'memória', 'espírito' não se distinguem tão facilmente. Não é também uma subjetividade introspectiva, mas se quer 'acordada' para seus próprios padrôes e hábitos mecanizados, se quer atenta e capaz de reagir às experiências que se apresentam. Por outro lado, não é uma subjetividade apenas reativa, moldada inteiramente pelos acontecimentos, jogada para lá e para cá ao sabor do vento, mas que faz escolhas rigorosas e 'ajusta-as' com vistas a poder seguir, arriscada e instavelmente, um percurso que lhe interessa.

Finalizo com uma história que muitos de nós conhecemos: Grotowski não permitia que se fizessem gravações em vídeo de $O$ Príncipe Constante, mas um espectador burlou a regra e fez uma gravação sem som. A essa gravação, encontrada em um mercado e comprada pela Universidade de Roma, anexou-se uma gravação de áudio. Essa última havia sido feita, anos antes, pela rádio de Oslo durante uma das apresentações do espetáculo. Entre a gravação em vídeo e a realizada em áudio havia, portanto, uma grande diferença de tempo, mas, quando da montagem, principalmente nos monólogos de Ryszard Cieslak, o som casou perfeitamente com a imagem. ${ }^{38}$ Salvo mitificações, não há dúvida ne- nhuma que temos aqui um exemplo de 'estrutura' extremamente detalhada feita com extrema 'precisão'. Por outro lado, inúmeros espectadores da época acreditavam estar vendo uma improvisação, tal era o grau de 'espontaneidade’ e engajamento do ator no espetáculo. Exemplo emblemático daquilo a que estamos nos referindo. Sim, mas como lidar com os exemplos emblemáticos? Em primeiro lugar, não tentando imitá-los no seu resultado final. É que a 'precisão’ pode se transformar em controle e limpeza de movimentos - com o objetivo de repetir perfeita e rigorosamente a 'estrutura' (mas estaríamos aqui falando da mesma 'precisão' a que Grotowski se referia?). E 'espontaneidade' pode se confundir com um bombeamento emocional que nos traz a impressão de 'desvendamento' e 'excesso'. O trabalho é sempre longo. $\mathrm{O}$ exemplo precisa ser reenviado à prática de cada um: perceber que, talvez, não seja o momento de 'fechar' excessivamente uma 'partitura', mas de deixá-la, ainda, 'aberta' às descobertas. Daqui a pouco, poderemos aprender, quem sabe, o que vem a ser 'detalhe' e 'precisão'. Talvez não devamos, também, colocar o nosso voluntarismo na caça de 'momentos preciosos' a serem compartilhados, mas perceber o que estimula o nosso interesse, o que nos faz sentido. E com certeza não é o momento de fechar uma definição para esse binômio, mas recolocá-lo em jogo nas experiências de todos nós. "Não ficar com os resíduos da festa que acabou, mas limpar a mesa e fazer uma nova festa." 39 E é para isso que dialogamos, seja com nossos companheiros de trabalho, seja com os textos e investigaçôes de Grotowski, Richards ou Biagini.

36 Grotowski relatou essa história no encontro em homenagem a Cieslak realizado em Paris em dezembro de 1990. Sua intervenção está transcrita no livro "Ryszard Cieslak, acteur-emblème des années soixante".

39 Não esqueci mais dessa frase desde que a ouvi em um vídeo dedicado ao movimento Fluxus. Infelizmente não tenho nenhuma referência desse vídeo. Essa declaração foi dada por um dos artistas que havia participado do movimento. Ao comentar a exposição de 'objetos fluxus' que estava sendo feita à época em um museu, ele disse não se reconhecer ali. Aquilo seria somente um 'final de festa' e a ele interessava sempre recomeçar a festejar, já que o movimento se queria ligado à vida (e não ao museu). A frase parece ser pertinente nessa conclusão. 


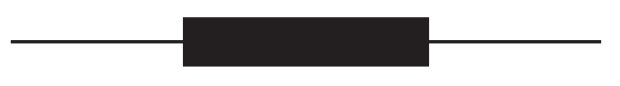

\section{Referências bibliográficas}

BIAGINI, M. “Incontro all'Università 'la Sapienza”. In: I Giganti della Montagna - rivista di cultura teatrale. Anno I n. 0, Roma, fevereiro, 2001.

BROOK, P. O Teatro e seu Espaço. Petrópolis: Vozes, 1970.

BUBER, M. Eu e Tu. Introd. e trad. de Newton Aquiles Von Zuben. São Paulo: Centauro, s/d.

BURZYNSKI, T. \& OSINSKI, Z. Le Laboratoire de Grotowski. Varsóvia: Editions Interpress, 1979.

CALVERT, D. "Heranças de Grotowski”. In: Revista Folhetim, n. 13, Rio de Janeiro: Teatro do Pequeno Gesto, abr-jun 2002.

FLASZEN, L. "Da mistero a mistero: alcune osservazioni in apertura". In: FLASZEN, L e POLLASTRELLI, C. Il Teatro Laboratorium di Jerzy Grotowski 1959-1969 - testi e materiali di Jerzy Grotowski e Ludwik Flaszen com uno scritto di Eugenio Barba. Pontedera: Fondazione Pontedera Teatro, 2001.

GROTOWSKI, J. "Giochiamo a Siva" [1960]. In: FLASZEN, L e POLLASTRELLI, C. Il Teatro Laboratorium di Jerzy Grotowski 1959-1969 - testi e materiali di Jerzy Grotowski e Ludwik Flaszen com uno scritto di Eugenio Barba. Pontedera: Fondazione Pontedera Teatro, 2001.

. "Farsa-Misterium” [dez. 1960]. In: FLASZEN, L e POLLASTRELLI, C. Il Teatro Laboratorium di Jerzy Grotowski 1959-1969 - testi e materiali di Jerzy Grotowski e Ludwik Flaszen com uno scritto di Eugenio Barba. Pontedera: Fondazione Pontedera Teatro, 2001.

"La possibilità del teatro" [fev. 1962]. In: FLASZEN, L e POLLASTRELLI, C. Il Teatro Laboratorium di Jerzy Grotowski 1959-1969 - testi e materiali di Jerzy Grotowski e Ludwik Flaszen com uno scritto di Eugenio Barba. Pontedera: Fondazione Pontedera Teatro, 2001.

. “O Novo Testamento do Teatro" [1964]. In: Em Busca de um Teatro Pobre. Rio de Janeiro: Civilização Brasileira, 1987.

. "Em Busca de um Teatro Pobre". In: Em Busca de um Teatro Pobre. Rio de Janeiro: Civilização Brasileira, 1987.

"O Discurso de Skara” [jan. 1966]. In: Em Busca de um Teatro Pobre. Rio de Janeiro: Civilização Brasileira, 1987.

"A Técnica do Ator" [1967].In: Em Busca de um Teatro Pobre. Rio de Janeiro: Civilização Brasileira, 1987.

"Ele não era inteiramente Ele" [abr. 1967]. In: Em Busca de um Teatro Pobre. Rio de Janeiro: Civilização Brasileira, 1987.

“O Encontro Americano" [dez. 1967]. In: Em Busca de um Teatro Pobre [1965]. Rio de Janeiro: Civilização Brasileira, 1987. 
. "Teatro e Rituale” [out. 1968]. In: FLASZEN, L e POLLASTRELLI, C. Il Teatro Laboratorium di Jerzy Grotowski 1959-1969 - testi e materiali di Jerzy Grotowski e Ludwik Flaszen com uno scritto di Eugenio Barba. Pontedera: Fondazione Pontedera Teatro, 2001.

. "Ezercizi” [mai. 1969]. In: FLASZEN, L e POLLASTRELLI, C. Il Teatro Laboratorium di Jerzy Grotowski 1959-1969 - testi e materiali di Jerzy Grotowski e Ludwik Flaszen com uno scritto di Eugenio Barba. Pontedera: Fondazione Pontedera Teatro, 2001.

. "Los Ejercicios" [mai. 1969]. In: Máscara - Cuaderno Iberoamericano de Reflexion sobre Escenologia (Grotowski) - ano 3- n. 11-12, México, janeiro de 1993.

. "Ce qui fut" [1970]. In : Jour saint et autres textes. Paris: Gallimard, 1973.

“Jour Saint" [dez. 1970]. In : Jour saint et autres textes. Paris: Gallimard, 1973.

. "Era como un Volcán”. In: Gurdjieff. Venezuela: Editorial Ganesha, julho de 1997.

"De la compagnie théâtrale à l'art comme véhicule". In: Travailler avec Grotowski sur les actions physiques. Paris: ActesSud/Académie Expérimentale des théâtres, 1995.

. "Programmi al Collège de France" [1996-1997]. In: Teatro e Storia 20-21, anno XIII, 1998-1999. Sull'attore e Grotowski Posdomani, Il Mulino.

. "Projet d'Enseigment et de Recherches - Antropologie Théâtrale, 1996”. Programa apresentado para candidatura ao Collège de France. Arquivo de Mario Biagini.

. "Le Prince constant de Ryszard Cieslak". In: BANU, G. Ryszard Cieslak, acteur emblème des années soixante. Paris: Actes Sud, 1992.

MAGNAT, Virginie. "Cette Vie n'est pas Suffisante: De l'acteur selon Stanislavski au performer selon Grotowski”. In: Thêatre/Public, 153, mai-juin 2000

MOTTA LIMA, T. “A arte como veículo”. In: Revista do Lume. N. 2, Campinas: UNICAMP, ago 1999.

OSINSKI, Z. Jerzy Grotowski: Zródla, inspiracje, konteksty. Gdansk: Slowo/Obraz terytoria, 1998.

OUAKNINE, S. "Les Voies de la Création Théâtrale". Volume I: "Théâtre Laboratoire de Wroclaw - Le Prince constant”. Introduction para Jean Jacquot. Étude et recontitution du déroulement du spectacle. Paris: Editions du Centre National de la Recherche Scientifique, 1970.

RICHARDS, T. Travailler avec Grotowski sur les actions physiques. Paris: ActesSud/Académie Expérimentale des théâtres, 1995.

. De L'Art comme Véhicule. Tese de doutoramento. Universidade Paris VIII, 2001.

STANISLAVSKI, C. El Trabajo del Actor sobre si mesmo. Tomo I: "En el proceso creador de las vivencias”. Buenos Aires: Editorial Quetzal, 1994.

. A Preparação do Ator. Rio de Janeiro: Civilização Brasileira, 1984.

SCHECHNER, R. \& WOLFORD, L. The Grotowski Sourcebook. New York: Routledge, 1997.

TOPORKOV, V. O. Stanislavski Dirige. Buenos Aires: Compañia General Fabril Editora, 1961. 